\title{
Incorporating International Financial Reporting Standards Into The United States Financial Reporting System: Timeline And Implications
}

RamMohan R. Yallapragada, Fayetteville State University, USA

\begin{abstract}
In the United States of America (US), all the accounting procedures and guidelines for measurement and reporting by business firms are governed by a body of principles and concepts known as "Generally Accepted Accounting Principles (GAAP)." These GAAP are presently issued by the Financial Accounting Standards Board (FASB) with the authority delegated by the Securities and Exchange Commission (SEC). Historically, each country developed its own GAAP and there was no uniformity among the GAAPs of different countries. Comparison of financial statements issued by business firms from different countries has become impossible leading toward suboptimal capital allocation across countries in the world. Gradually, with the advent of multinational corporations, there emerged a global demand for convergence of GAAP of different countries into a single set uniform accounting standards applicable to all countries. Initiative for uniform global accounting standards came from International Accounting Standards Committee (IASC) which was established in 1973. The IASC formed International Accounting Standards Board (IASB) in 2001 which began issuing International Financial Accounting Standards (IFRS). Till now about 100 countries have adopted IFRS for their financial reporting purposes. The SEC has yielded to the global pressure to adopt IFRS in the US. SEC has set a timeline for US business firms to change over from US GAAP to IFRS. This paper presents the background and development of the movement of IFRS, timeline for the change in US and the implications involved in the adoption of IFRS in the US.
\end{abstract}

Keywords: GAAP; IFRS; FASB; SEC; Securities and Exchange Commission; IASB; Uniform Global Accounting Standards

\section{INTRODUCTION}

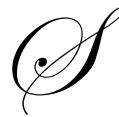

urprisingly, it may not be known to many people of this generation that public companies in the United States (US) were not always required to prepare and submit financial reports in accordance with a uniform set of standardized accounting procedures. It may be even more surprising to note that public companies in the US were not always required to issue financial statements at all (Phillips, 2010). In fact most decisions for investing billions of dollars in stocks during the period before the stock market collapse of October 1929 were made without the help of any financial information about the companies in which the investments were made. As a direct result of the market crash, US Congress enacted the Securities Act of 1933 and the Securities Exchange Act of 1934, requiring companies to make some disclosures and to avoid fraud. The advent of these securities laws launched a movement for bringing some comparability among the financial situations of different companies, making it necessary to establish a uniform system of financial reporting. In 1933, the American Institute of Accountants (AIA), the predecessor of the American Institute of Public Accountants (AICPA) adopted six broad principles of financial reports which later came to be known as the Generally Accepted Accounting Principles (GAAP). Gradually, various standard setting bodies came into being and began to issue authoritative rules and guidelines of accounting procedures which together constituted the body presently existing GAAP (Phillips, 2010). These GAAP 
govern the accounting measurement and reporting procedures in the US today. The first standard-setting group appointed by AICPA to deal with the issue of uniformity in accounting procedures was the Committee on Accounting Procedures (CAP). CAP served from1939 to 1959 and issued 51 Accounting Research Bulletins (ARB). In 1959, AICPA substituted CAP by creating the Accounting Principles Board (APB). Its pronouncements were known as APB Opinions. In 1973, a committee, known as the "Wheat Committee," was appointed to improve on the operations of the APB. The result was replacement of APB by the creation of Financial Accounting Standards Board in 1973, which consisted of full-time members with greater autonomy. The FASB is the current rule-making body and issues Statements of Financial Accounting Standards. The pronouncement of the CAP, the APB and the FASB together constitute the present set of accounting standards in the US, known as the GAAP.

\section{INTERNATIONAL ACCOUNTING STANDARDS BOARD}

In the past, each country developed and followed its own unique accounting standards. There were vast differences in accounting measurement and reporting procedures of different countries, making it impossible to compare and evaluate financial information of companies from different countries. Consequently, there was difficulty in movement of capital across the borders leading to inefficient global capital utilization (Wiecek and Young, 2010). With the advent of multinational corporations operating across borders of different countries, there emerged a movement among accounting professionals in various countries towards achieving convergence of GAAPs of different countries into a single set of uniform accounting procedures equally applicable to business firms in all countries in the world.

The most prominent movement towards international accounting standards came in 1973 by the establishment of "International Accounting Standards Committee" (IASC), a private body whose members included accounting professionals from many countries, including the US. The IASC was founded as a vehicle for harmonizing accounting practices throughout the world (Ruder et al., 2005). In 1998, the IASC completed a set of basic international accounting standards. The International Accounting Standards Board (IASB) was formed in 2001 to replace the IASC, with a mandate to develop and approve pronouncements known as International Financial Reporting Standards (IFRS) (Poon, 2010). The IASB operates under the oversight of the IFRS Foundation. The objectives of the IASB are:

a). to develop, in the public interest, a single set of high quality, understandable and enforceable global accounting standards that require high quality, transparent and comparable information in financial statements and other financial reporting to help participants in the world's capital markets and other users make economic decisions.

b). $\quad$ to promote the use and rigorous application of those standards;

c). In fulfilling the objectives associated with (a) and (b), to take account of, as appropriate, the special needs of small and medium-sized entities and emerging economies; and

d). to bring about convergence of national accounting standards and International Accounting Standards and International Financial Reporting Standards to high quality solutions.

(Source: http://www.iasplus.com/restruct/whatis.htm)

A major impetus to the widespread adoption of IFRS was given in 2005 when the European Union, (EU) comprising of half of the world's economy, decided to adopt the IFRS. As Kotlyar (2008) observes, "the EU decision provided momentum toward a single set of standards throughout the world by promoting a domino effect within other countries. To date, it has become a global phenomenon with approximately 12,000 companies in over 100 countries requiring the use of IFRS."

\section{TIMELINE FOR ADOPTION OF IFRS IN THE UNITED STATES}

\section{Norwalk Agreement (2002)}

The AICPA has been, for a long time, calling for reducing the differences between accounting and reporting procedures of public companies in the US and those in other countries, thus paving the way for facilitating 
cross-border capital movement (Melancon, 2010). The first sincere effort for achieving this objective was made in October 2002 when the FASB and the IASB together issued a Memorandum of Understanding, known as the "Norwalk Agreement." This agreement formally recognized convergence as an avowed goal of these two standardsetters (Hopkins, et al., 2008). Since then, the two boards have been actively working towards reducing differences between the US GAAP and IFRS, engaging in several convergence projects. Consequently, differences in many areas such as inventory, discontinued operations, etc., have been reduced. However, there are still some significant differences, as for example, in the area of revenue recognition (Hopkins, et al., 2008).

\section{Elimination Of Form 20-F Reconciliation Requirement (2007)}

Under previous SEC regulations, all foreign issuers registering with the SEC are required to complete Form 20-F under section 12 of the Securities Exchange Act Of 1934. Foreign companies registered with the SEC are then required to file their annual and periodical financial reports in accordance with US GAAP, or in accordance with their local GAAP (IFRS), "accompanied by a reconciliation with the US GAAP." This requirement of preparing and filing two sets of financial statements under two different sets of accounting standards resulted in considerable effort and cost to foreign companies registered with the SEC (Erchinger and Winfried, 2007).

In December 2007, the SEC unanimously voted to eliminate this very costly requirement for companies listed on US exchanges to reconcile their IFRS-based financial statements to the US GAAP (James, 2008). Posner (2008) states that, the US regulators (SEC)"ushered in a mutual recognition regime - a form of sovereignty sharing, perhaps unprecedented in SEC history - by lifting the reconciliation requirement for foreign listed companies using IFRS ..”

In a call for comments on its proposal for elimination of the reconciliation requirement, the SEC raised questions regarding five issues:

1). Are IFRS 'quality' accounting standards?

2). Should acceptance of IFRS-based accounting standards be contingent upon convergence of US GAAP and IFRS standards?

3). Should the timing of acceptance of IFRS-based financial statements depend On foreign issuers, audit firms, and other constituents having more experience with preparing IFRS-based financial statements?

4). How useful is the reconciliation of US GAAP and IFRS for comparing different companies?

5). Do you agree with our assessment of costs and benefits?

(Source: Jamal, 2008)

\section{SEC Road Map (2008)}

On August 27, 2008, the SEC proposed a 'Road Map" in which deadlines were specified for US companies to adopt IFRS. Starting with their annual reports for 2009, the largest US public companies may switch over from US GAAP to IFRS, followed by waves of other companies, until 2016, the final deadline for adoption of IFRS even by the smallest companies (Hansen, 2008). The SEC also suggested that FASB and IASB would continue to work toward convergence through 2011. At that time, the SEC will evaluate if IFRS is of "high quality and sufficiently comprehensive". If IFRS meets the requirements, the U. S. companies could be required to use IFRS (in a phased manner) by the year 2016 (Rahr et.al. 2010). The SEC justified its position on the adoption of IFRS on two counts: (1). US companies would continue to retain comparability among U. S. companies while attaining similar comparability with companies in other countries; and (2). it provides U. S. companies with greater opportunity to compete in global markets. Additionally, adoption of IFRS received some more impetus recently, when the G-20 leaders, at their meeting in 2009 , urged the accounting standard setters to agree on a single set of high quality global accounting standards (Rahr et.al. 2010).

According to Morgan (2008), the proposed road map is nothing short of a monumental undertaking aiming to facilitate the switch over by all US companies from the rule-based US GAAP to the principles-based IFRS. In its 
road map, the SEC included seven milestones to be reached by 2011 before the commission makes its final decision as to whether or not to proceed with the adoption of IFRS. The seven milestones are:

1). Improvements in financial reporting such as adoption of summary prospectus rules and the proposed adoption of XBRL reporting language and tagging requirements.

2). Evaluation of funding and accountability of the London-based IASB Foundation and the IASB (which are private bodies).

3). Improvements regarding the interactive data tags for IFRS.

4). IFRS education and training.

5). $\quad$ Early adoption of IFRS by eligible companies.

6). Timing of future rulemaking for regulatory harmony and for promoting mandatory rather than voluntary adoption of IFRS.

7). Readiness of large companies to adopt IFRS.

(Source: Morgan, 2008)

The gradual switch over to IFRS contained in the road map envisages IFRS adoption by large filers (on or before) December 15, 2014, by medium-size companies (on or before) December 15 2015, and by all other companies by December 15, 2016 (Morgan, 2008).

\section{SEC Work Plan (2010)}

On February 24, 2010, the SEC unanimously voted to announce its support towards achieving the goal of formulating a single set of high-quality, globally accepted accounting standards. The SEC also renewed its support for continuous effort for convergence of US GAAP and IFRS. The FASB, along with the IASB, expressed commitment to complete their major convergence projects by June 2011. In the same announcement, the SEC also directed its staff to develop a 'Work Plan' that would enable the SEC to evaluate the impact of adoption of IFRS by US companies on the US capital markets. If the convergence projects and the Work Plan are completed by 2011, the SEC would then decide whether or not to incorporate IFRS into the US financial reporting requirements, including the timeline thereof (Melancon, 2010) The SEC work plan includes the following six issues:

1). The quality of IFRS and their suitability for adoption in the US.

2). Ensuring that standards are set by independent standard-setters and for the benefit of the issuers.

3). Investor understanding and education regarding IFRS and their differences from US GAAP.

4). Whether any US laws and regulations, other than those of securities and reporting, would be affected by adoption of IFRS.

5). The impact of adoption on US issuers.

6). Readiness of the parties, involved in preparation and auditing of financial statements, for the adoption of IFRS.

(Source: DeFelice and Lamoreaux, 2010)

\section{The Push Back}

In October 2010, the chairs of FASB and IASB together announced a push back of the deadlines previously set for completing some of their convergence projects, "from June 2011 to the end of 2011," (Cohn, 2010). In April 2011, the two chairs again announced in a joint podcast that they have decided to extend the time table for completing a few priority convergence projects for a few more additional months to enable them, "to check whether our conclusions would stand the test of time, and to ensure that the standards are of the highest quality," (Conn, 2011). 


\section{SUMMARY CONCLUSIONS AND RECOMMENDATIONS}

\section{Summary}

The historic crash of US capital markets in October 1929 brought to surface the dire need for establishing some uniform rules and principles for financial reporting in the US. The standards setting bodies, AICPA Committee on Accounting Procedures, the Accounting Principles Board and the FASB, under the supervision of the SEC, have assiduously developed a set of guidelines for accounting measurement and reporting, famously known as 'Generally Accepted Accounting Procedures' (GAAP). These GAAP were developed through a laborious and democratic process. Investors in US companies from all over the world considered "the US GAAP as the Gold Standard, a transparent system for reporting earnings and financial information ---. A decade ago, junking these US GAAP would have seemed preposterous,"

(Henry, 2008).

Sweeping changes have occurred in the capital market environment all over the world in the past two or three decades. Gradually, the markets have become more and more global in nature. US investors have more opportunities for cross-border investments. The SEC began to notice this phenomenon and started to voice its support for a single set of high quality, globally applicable financial reporting standards, in order to promote greater comparability of financial reports between US and non-US companies. The IASB was established in 2001 and began issuing the IFRS. Major capital markets all over the rest of the world except US began to use IFRS and more and more countries are expected to follow suit. To date, about 12,000 companies from over 100 countries around the world have adopted IFRS. Starting in 2002, the SEC has set a timetable for achieving convergence of US GAAP and IFRS, by issuing a road map and a work plan to achieve full adoption of IFRS by US companies before the end of 2016.

\section{Conclusions}

It seems almost certain that the SEC has launched itself and the US on an inexorable path toward full adoption of IFRS by all US companies in the near future. Many believe that such adoption would benefit both US and non-US companies and also capital markets all over the world because of the increased comparability of performance of companies across the globe whose financial reports are prepared using a single set of uniform global standards. There are others who claim that US GAAP are rule-based, with strict objective standards of measurement and reporting whereas, the IFRS are principles-based providing greater room for subjective judgment and valuation of accounting elements. For instance, the US GAAP are firmly based on the bedrock of historical cost for valuation of most assets. Contrarily, IFRS allows 'fair value' for the same purpose. What is 'fair value' is anybody's guess. There are many accounting professional who express great concern that many aspects of IFRS contribute toward confusion in interpretation of financial statements and work against accurate comparability of financial reports of companies from different countries. Still many others express their doubts as to whether the SEC has the legal authority to delegate its regulatory powers regarding financial reporting by US companies to a foreign, private body of standard-setters. Also, there are many doubts about the preparedness of US Business schools for handling this transition to IFRS. US companies are still reeling from the headache and increased costs involved in implementing provisions of Sarbanes-Oxley Act of 2002. As Gray (2007) points out, these companies are now facing a veritable migraine that would visit them in the laborious process of switching over to IFRS. The writing on the wall seems to point towards the inevitable and eventual adoption of IFRS by US companies.

\section{Recommendations}

In spite of the seemingly inflexible road map of the SEC for the adoption of IFRS in the US, there are still some serious questions about the feasibility, the advisability, and the desirability of adoption of IFRS. This is a current and continuing problem. Extensive further research is needed to explore the possible consequences, beneficial as well as harmful, arising out of the IFRS adoption. Further research is also recommended to investigate questions as to whether adoption of IFRS in the US is legal, and whether such adoption is actually beneficial to US companies and US capital markets. Research is also necessary to investigate the impact of the IFRS adoption on future students and educators in business disciplines and on the US professionals in public accounting. 


\section{AUTHOR INFORMATION}

RamMohan R. Yallapragada is an Associate Professor of Accounting at Fayetteville State University. He obtained his PhD degree in Accounting from the University of Houston. He holds a CPA certificate from the State of Louisiana. He taught at University of Texas at San Antonio, Nicholls State University, and University of Louisiana, Lafayette before joining FSU. He has published in several journals including Journal of Business and Economic Research, International Business and Economic Research Journal, Journal of Accounting and Finance Research, and Clarion Business and Economic Review. His research areas include Cost Accounting in Healthcare, Accounting irregularities in Fannie Mae, and impact of Sarbanes-Oxley Act of 2002 on American corporations. E-mail: ryallapr@uncfsu.edu.

\section{REFERENCES}

1. Cohn, Michael (2011). "FASB and IASB Delay Convergence Timeline Again,” Accounting Today, April 14, 2011.

2. (2010). "FASB and IASB Rejigger Convergence Plans," Accounting Today, October, 2010.

3. DeFelice, Alexandra and Matthew G. Lamoreaux (2010). "The SEC IFRS Work Plan," Journal of Accountancy, Vol. 209, Issue 4, April 2010, pp. 22-25.

4. $\quad$ Erchinger, Holger and Winfried Melcher (2007). "Convergence Between US GAAP and IFRS: Acceptance of IFRS by the US Securities and Exchange Commission (SEC)," Accounting in Europe, Vol. 4, Issue 2, 2007, pp. 123-139.

5. G Gray, John (2007), "More Headaches with Numbers," Canadian Business, Vol. 81, Issue 1, December 24, 2007, p. 18.

6. Hansen, Fay (2008). “Kiss GAAP Goodbye,” Workforce Management, Vol. 87, Issue 15, September 28, 2008, pp 16-17.

7. Henry, David (2008). “A Better Way To Keep The Books,” BusinessWeek, Issue 4099, September 15, 2008, p. 35.

8. Hopkins, Patrick E. et al. (2008). "Response to the SEC Release, 'Acceptance from Foreign Private Issuers of Financial Statements Prepared in Accordance with International Financial Reporting Standards Without Reconciliation to U. S. GAAP File No. S7-13-07,"” Accounting Horizons, Vol. 22, No. 2, June 2008, pp. 223-240.

9. Jamal, Karim, et al. (2008). “A Perspective on the SEC's Proposal to Accept Financial Statements Prepared in Accordance with International Financial Reporting Standards (IFRS) without Reconciliation to U. S. GAAP," Accounting Horizons, Vol. 22, No. 2, June 2008, pp. 241-248.

10. James, Marianne (2008). “Accounting Majors’ Ability to Identify Financial Reporting Errors and Omission and the Convergence Between U. S. GAAP and International Financial Reporting Standards," Proceedings of the Academy of Accounting \& Financial Studies, Vol. 13, Issue 2, October 2008, pp. 14-18.

11. Kotlyar, Julia (2008), "The Advent of The International Financial Reporting Standards: A Catalyst for Changing Global Finance,” Journal of International Affairs, Vol. 62, Issue 1, Fall/Winter 2008, pp. 231 238.

12. Melancon, Barry C. (2010), "The Global Accounting Profession in the United States," International Journal of Disclosure \& Governance, Vol. 7, Issue 4, November 2010, pp. 294-297.

13. Morgan John (2008), "SEC Launches International Accounting Road Map Proposal to be Monumental Undertaking for U. S. Companies," Money Management Executive, Vol. 16, No. 46, December 1, 2008.

14. Phillips, Lance J. (2010), "The Implications of IFRS on the Functioning of the Securities Antifraud Regime in the United States," Michigan Law Review, Vol. 108, Issue 4, February 2010, pp. 603-631.

15. Poon, Wing W. (2010), "SEC Work Plan for the Consideration of Incorporating IFRS into the U. S. Financial Reporting System,” Proceedings of the Northeast Business \& Economics Association 2010, pp. 101-104.

16. Posner, Elliot (2008), "Internal Sources of Global Regulatory Power: The New International Regime in Accounting Standards," Conference Paper, International Studies Association2008 Annual Convention, San Francisco, March 26-29, 2008, pp. 1-35.

17. Rahr, K., K. E. Karim, and R. W. Rutledge (2010), “Transitioning to IFRS," CPA Journal, Vol. 80, No. 3, March 2010, pp. 6-8. 
18. Ruder, David S. et al., (2005), "Creation of Worldwide Accounting Standards: Convergence \& Independence," Northwestern Journal of International Law and Business, Symposium on the Convergence of Accounting Standards, Spring 2005.

19. Wicek, Irene M. and Nicola M. Young (2010), "IFRS Primer: International GAAP Basics, U. S. Edition", John Wiley \& Sons, Hoboken, NJ 2010

20. www.iasb.org 
NOTES 